Original scientific paper

UDK: 070:316.019.5

$327.7(323(1-664))$

DOI: $10.5937 /$ jrs15-23579

Received: 14 October 2019 / Accepted: 28 April 2020

\title{
Populist Communication in the Post-Truth Age: A Comparative Analysis of Treatment of Journalists by Donald Trump and Aleksandar Vučić
}

\author{
MILICA KULIĆ* \\ University of Belgrade, Faculty of Political Science, Serbia
}

\begin{abstract}
The populist communication model of perceiving journalists as "the enemies of the state", presented in the political communication of the $45^{\text {th }}$ US President Donald Trump, seems to be not only reserved for the US but has become a trend for populist leaders worldwide. Such rhetoric has been revitalized by the recent rise of populism in Western Europe, fostered in Central and Eastern Europe and recognized in the local media landscape in Serbia. This paper compares the communication models of US President Donald Trump and the Serbian President Aleksandar Vučić as directed toward journalists. The results show that these leaders use a similar communication pattern: they favour divisive issues, stressing a friendly vs. unpatriotic media, alienating the media outlets and contributing to the further polarisation in media and society. This research is based on a qualitative analysis of 12 press conferences, including media statements chosen for their unique interactions with media representatives.
\end{abstract}

Keywords: political communication, populism, Donald Trump, Aleksandar Vučić, post-truth

\section{Introduction}

In his foreword to Richard H. Rovere's book Senator Joe McCarthy, Arthur M. Schlesinger wrote: "Once the season of paranoia is over, we look back with certain disbelief at our spasms of irrationality. Later generations reading about Joe McCarthy must wonder what in the world their ancestors had been smoking in the 1950s." In this same reflective manner, it is likely that future generations will ask how it had been possible, despite absolute globalization, an "open" era of almost unquestionable facts and under the universal inclusion of social networks, that journalists have been marginalized by the political establishment. These questions most easily arise while highlighting the obvious instances of media in the United States "where antagonism toward journalists has already been a regular feature of political discourse." Journalists feel this antagonism while facing the "venomous attacks of Donald Trump." 3 They are denounced in political circumstances and "sub-

*milica.jevtic@fpn.bg.ac.rs 
jected to racist and misogynistic taunts". ${ }^{4}$ As writer and media analyst Michael Massing concluded: "Journalists feel under siege like never before".

The existing attitude towards the media is represented in the outright denunciation of its representatives/journalists. Once heralded, even theoretically, as truth tellers and sources of reliable information, they are now widely perceived as "unpatriotic elements". It seems that this political "culture" is not only reserved for the US, but has become a modern and widespread model for the growing number of "strong", populist, leaders worldwide. This malign attitude toward journalists has emerged in the context of political polarisation and a crisis of democracy, ${ }^{6}$ where there has been a distinct rise in populism and the masssupport actively given to populist leaders and their parties in Western countries, ${ }^{7}$ as well as "democratic backsliding". The context is shaped by the phenomenon of a post-truth paradigm, ${ }^{9}$ but also by the erosion of the public trust in journalism, ${ }^{10}$ a clash of journalistic authority ${ }^{11}$ and an erosion of the professional identity ${ }^{12}$ itself. These factors are not the only ones that contribute to shaping the antagonism toward journalists as political discourse; rather, they are the framework of the global political perspective that reflects within the media itself.

Although polarisation is generally perceived as a threat to democracy, ${ }^{13}$ it is equally an opportunity to "mobilize society" to act and "achieve fundamental changes in structures, institutions, and power relations". ${ }^{14}$ A free press, as the fifth estate in its watchdog role, the media has been perceived as integral to democracy - which is the reason it has been under attack. With the rise of populism, mostly in the Trump and Brexit era, ${ }^{15}$ the broader media scene as a global role model present within Western democracies, may be exported to local landscapes worldwide. The rise of populism is not only driven by economic policies $^{16}$ but by "cultural backlash"17 and "social policies" ${ }^{18}$ as well. Local contexts and local habits, therefore, also shape populism to the leader's style and their national context. If the

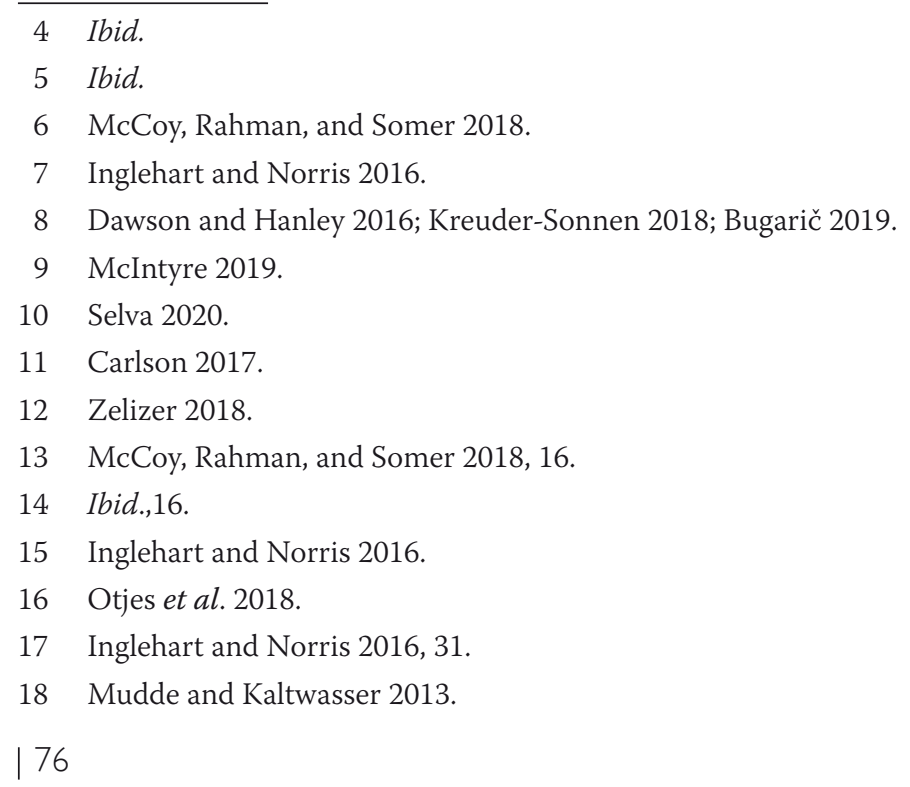


antagonism towards journalists and journalism is capable of existing in those countries whose institutions remain strong and predictable, there are even fewer barriers to the same antagonism in those countries where these institutions are weaker and less reliable.

Despite the continuous decline of the US in the press media index (stemming mostly from within the last four years of the Trump administration), ${ }^{19}$ the United States is still perceived as a model of the media's struggle for rights in countries headed by strong-arm leaders. This perception is due to the United States' strong media-market, the supremacy of its system and its institutions toward political representation, as well as the prominence and influence of its corresponding media outlets. Journalists have been encouraged, as their constitutional right in the United States, to insist on their press freedom - such as when a Federal Court ordered the White House to return the press-pass of CNN correspondent Jim Acosta after the Trump administration had revoked it following Acosta's direct questioning of the administration..$^{20}$ Applying the First Amendment to social-media, the Court of Appeals ruled that President Trump does not have the authority to exclude Americans from reading his posts on Twitter and responding to them because he does not like their views ${ }^{21}$ Regardless, despite all these decisions which indicate legal certainty and even though "the National news organizations have adopted grand slogans like 'Democracy dies in darkness' (The Washington Post) and 'The truth demands our attention' (The New York Times),"22 American journalists have seen their position worsen in relation to their right to report on political authorities.

Unfortunately, journalism's shifting position from "watchdog" to "lap dog" has been disseminated worldwide amid political, economic and institutional uncertainty. Turkish journalists accused President Recep Tayyip Erdoğan of a "media witch-hunt like McCarthyism". ${ }^{23}$ Independent journalists in Hungary have stated that they "operate in a ghetto." ${ }^{24}$ This and similar models of accusing journalists of working against the state have been replicated in the Western Balkans: the Croatian Prime Minister has accused a journalist of being an activist instead of a journalist; ${ }^{25}$ the Serbian President has accused a cable TV station of being instructed both by opposition leaders and by its foreign ownership. ${ }^{26}$ Serbia's complex relationship between its media and political authorities, where "media associations reported that political, economic, and other pressures on journalists increased," ${ }^{27}$ have taken on a new dimension reflecting a lack of an institutional frame-

19 Reporters Without Borders 2019.

20 Stelter et al. 2018.

21 Savage 2019.

22 Massing 2018.

23 Shaheen 2016.

24 Berardi 2019.

$25 \quad$ N1 2019.

$26 \quad$ N1 2018.

27 European Commission 2019. 
work, the rule of law and institutional predictability. Serbia has dropped 14 places on the World Press Freedom Index in 2019. Within the last five years of Vučić's premiership and presidency, Serbia has become "a place where practicing journalism is neither safe nor supported by the state". 28 The number of attacks on the media in Serbia is also on the rise, including "death threats and inflammatory rhetoric targeting journalists increasingly coming from the governing officials". ${ }^{29}$ While Freedom House has ranked Serbia as partly free for the first time in over a decade, it also cited that Serbia "has steadily eroded political rights and civil liberties, putting pressure on independent media". ${ }^{30}$ The Freedom House report showed that Viktor Orbán and Aleksandar Vučić succeeded in "snuffing out critical journalism, blazing a trail for populist forces elsewhere". ${ }^{31}$ Both leaders consolidated media ownership "in the hands of their cronies", ensuring that "the outlets with the widest reach support the government and smear its perceived opponents".32

This paper aims to shed light on similarities of how populist leaders in the post-truth era share attitudes toward journalists. Bearing in mind the global context and its local implications in weak democracies (such as Serbia), the article will compare patterns in political communication toward journalists of the presidents Donald Trump and Aleksandar Vučić. These political leaders, while different in their backgrounds and the manner they conduct their administrations, share similar methods in how they approach, deal with and demonize the media they don't like.

Trump, as the president of a significant world power, has legitimized hostile political communication against journalists worldwide. Contrary to his previous right-wing, proRussian orientation (since 2008), Vučić has rebranded himself in his rise to power, proclaiming his orientation to the EU and other Western-styled democracies, either following external pressures from the EU or wishing to be perceived as such. Vučić has openly promoted these same trends of open hostility toward the press in Serbia, which therefore makes him an appropriate example for comparison. This article addresses the gap between a rising interest in researching populism and democratization (global and local) and research on media capture ${ }^{33}$ the role of the media and the media system, especially in weak democracies. ${ }^{34}$ The research comes in a moment of a frequent comparison of the communication models of the two leaders in public discourse..$^{35}$

\footnotetext{
28 Reporters Without Borders 2019a.

29 Ibid.

30 Freedom House Report 2019.

31 Ibid.

32 Freedom House Report 2019.

33 Milosavljević and Polar 2018.

$34 . \quad$ Mladenov Jovanović 2018.

35 The media adviser of President Vučić compared, on the pro-government TV Pink, the behaviour of the two presidents regarding the case of Jim Acosta, explaining that the US President revoked the journalist's press cards, which the Serbian president never did. See: Pavkov 2019.
} 
This paper is divided into five sections: the first will contextualize the post-truth era in order to clarify the new tendencies in politics and the media as well. The second part will offer the context of polarization combined with populism and media populism in Western democracies, democratic backsliding and the local landscape. The third part will discuss the theoretical definition of populism (ideology and style) in order to show that both leaders use similar populist techniques of communication. This framework will be used to define codes which will be applied to the political communication of Trump and Vučić which is at the core of the analysis. In the conclusion, the paper will discuss the results found regarding the similarities and differences between the two leaders.

\section{Post-Truth, Public Opinion and Role of Journalists}

The contextualization and understanding of the truth in the era in which we live is crucial for this article's argument. It is paradoxical that, when "truth" may be more accessible than ever due to the development of globalized and networked communication, it is actively being bypassed by misconceptions, misperceptions and propaganda of outright, easily provable lies. These paradoxes are framed by the term "post-truth", based on the context in which "objective facts are less influential in shaping public opinion than appeals to emotion and personal belief" ${ }^{36}$ The term, which Oxford dictionary proclaimed to be the word of the year in 2016, may seem blurred and unclear. Lee McIntyre has stated that post-truth:

Amounts to a form of ideological supremacy, whereby its practitioners are trying to compel someone to believe in something whether there is good evidence for it or not. And this is a recipe for political domination. ${ }^{37}$

Post-truth itself is better understood in this context to be defined according to how it is presented in political behaviour worldwide. Post-truth politicians generally share the characteristic that they "manufacture their own facts" 38 and assert "whatever they believe to be in their own interest and continue to press those same claims, regardless of the evidence amassed against them" ${ }^{39}$ Those who operate in a post-truth era most successfully promote an "authoritarian impulse" ${ }^{40}$ which goes hand in hand with "propaganda, vilification and intimidation".

\footnotetext{
36 Oxford Dictionary n.d.

37 McIntyre 2019, 13.

38 Lockie 2017, 1.

39 Ibid., 1.

40 Lockie 2017, 1.

41 Ibid.
} 
Natural biases promoted by "filter bubbles" and "echo chambers" that social networks help promote ${ }^{42}$ tend to shape public opinion, which has natural political ramifications. As the light of truth is being slowly extinguished, Habermas's public sphere of "a realm of our social life in which something approaching public opinion can be formed"43 has been replaced with an "increasingly segmented niche audience"44 and the "growth of niche identity groups and the increasing intensity of partisanship politics" ${ }^{35}$ whose internecine arguments have nearly strangled any effective ability to form critical pressure on political authorities. In some cases, journalism has abandoned its role to inform its audience, ${ }^{46}$ whereby journalists have contributed to the fragmentation of social discourse, furthering division and polarisation of the audience. Polarising the media sphere between media outlets "for the people" and "for the elite", following the principle "for the rest and the best", forcing an "opinion dog" 47 instead of watchdog journalism, have all contributed to a divided and polarised political atmosphere which populists have misappropriated. While exercising near aristocratic privileges to criticize journalists, political leaders have equated journalists with global capital and private interest groups, which has further induced "deep levels of professional conviction" among journalists. ${ }^{48}$ What is more, is that journalists have become news themselves; they "obtain a central role in media politics when it provokes attention back toward itself", ${ }^{49}$ creating a narrative and contributing to the polarisation between the media, as well as the media and the political establishment.

\section{Polarisation and (Media) Populism}

Just like populism and post-truth, polarisation has become the "new normal", 50 whereby old political divides have been replicated into all forms of the political spectrum and mutated into strict social circles based on decided loyalties. According to McCoy, Rahman and Somer, polarisation may be defined as:

A process whereby the normal multiplicity of differences in a society increasingly align along a single dimension, cross-cutting differences become instead reinforcing, and people increasingly perceive and describe politics and society in terms of "Us" versus "Them". 51

42 Bakshy, Messing, and Adamic 2015, 1130.

43 Habermas 1974, 49.

44 Pepper 2005, 82.

45 Freie 2012, 323.

46 Coleman, and Morrison 2009.

47 Pope 2019.

48 McDevitt and Ferrucci 2017, 512.

49 Ibid., 512.

50 Block and Negrine 2017, 190.

51 McCoy, Rahman, and Somer 2018, 18. 
"Trump's starkly polarising and anti-establishment, dividing" ${ }^{2}$ campaign rhetoric is one prime example of the utilization of polarisation among political leaders. Deepening the process and existing cleavages, Trump's example goes above and beyond the United States, as it "has pernicious consequences for democracy". ${ }^{33}$ In the US, polarisation including "animosity toward opposition" has been on the rise over the last decade ${ }^{54}$ where a majority of "voters in 2016 said that people supporting the opposition anger and even scare them.".55 Trump exploits these feelings, being a "terrible simplificateur".56 Domestically, it divides the voting base ensuring loyal supporters; yet, when applied to foreign policy, it worsens international polarisation in which the Trump administration creates an international environment of "the U.S. versus others" ${ }^{\text {" }} 7$ The extreme use of polarisation for political purposes results in "fostering cultural and social anxiety among people, especially against the media and politicians".58

Although polarisation risks "instability, democratic erosion and democratic collapse", 59 its true danger is that it is frequently coupled with populism, a political practice "easily instrumentalized by almost any type of ideology". ${ }^{60}$ The rise of populism is not merely the proclamation of a dominant ideology or dominant style, it seeks for "disintegration" 1 and carries with it "the spectre of authoritarianism,"62 as populism seems to espouse as its driving force to "erode the substance of democracy and gradually transform it into various forms of illiberal and authoritarian regimes" ${ }^{63}$ Populism sustains itself across a national phenomenon, linking similar behavioural patterns and forms in local politics, which build a "cycle of authoritarianism".64 Most alarmingly, although populism takes on much flavour locally as it varies from country to country, one of its constants is the ineffectiveness of institutions to combat them.

Research into democratic factors in Central and Eastern Europe generally cites polarisation and populism as being the main factors behind democratic backslides. As members of the EU have shown that determined populist leaders role back hard-won rights, Hungary and Poland are often cited as prime examples of a "new populism" that combines

\footnotetext{
52 Ibid., 18.

53 McCoy, Rahman, and Somer 2018, 35.

54 Strandberg et al. 2020, 2.

55 Ibid., 2.

56 Doner 2019, 125.

57 Ibid., 125.

58 Ibid.

59 Somer and McCoy 2019, 9.

60 Bugarič 2019, 598.

61 Kreuder-Sonnen 2018, 453.

62 Ibid., 453.

63 Muller, in Bugarič 2019, 599.

64 Kreuder-Sonnen 2018, 453.
} 
"elements of populism, ethno-nationalism, and authoritarianism". Although formally EU member states, these countries are "increasingly undermined by popular distrust", consisting of "corrupt and collusive relationships linking business, media, and political elites and periodic eruptions of civic anger and anti-elite populism". Populism is seen elsewhere rising in "young democracies", such as the Western Balkan countries, even if a majority of these countries are trying to meet their commitments to join the EU through the preaccession process.

Political populism is coupled by "media populism" and the medialization of political communication, in which there is a circular feedback in the media market as it is strongly shaped by political circumstances and vice versa. Explaining Trump's rhetoric in the context of populism and media populism can "clarify something similar that has been happening in many modern democracies". ${ }^{65}$ Elena Block and Ralph Negrine compared Donald Trump to other populist leaders, from Nigel Farage in the United Kingdom, Marine Le Pen in France, Pauline Hanson in Australia to Alexis Tsipras in Greece and Pablo Iglesias in Spain. The authors conclude that these political leaders all share two qualities:

They have all been associated with right- or left-wing forms of populism and have been recognized for their savvy use of media communication. ${ }^{66}$

Gianpietro Mazzoleni links populism and the media, claiming that the latter provides significant support to the rise of populist phenomena. He concludes that populism shows a unique alliance of media and political factors but the main catalyst "may be found in the country's political culture at a given time" ${ }^{67}$ The relationship between populism and the media is certainly shaped by political culture, but the legal framework in which populism arises should also be taken into consideration.

From the early 1990s until today, young democracies emerging from post-communist countries have suffered from a lack of legal institutional supremacy that has supported the rise of populism and populist messages. Indeed, post-communist countries have been actively turning to populism as it is a "natural mode of politics in a country where the postcommunist electorate represents the largest voter segment". ${ }^{8}$ The media is both a means and a target as any failure to comply with a populist message, whether it is true or plagued by falsehoods, results in the media becoming the "victim" of populist leaders. Journalists and the media are easy scapegoats since they are not a coherent group or community. The issue dividing communities, hence, also drives the polarisation between media outlets as they seek to cater to their audience(s). As populists are trying to incorporate direct references to "a will of people, opportunism, the construction of moral majority and promise

65 Rowland 2019, 345.

66 Block and Negrine 2017,178.

67 Mazzoleni 2008, 50.

68 Csigo and Markovity 2017, 302. 
of state defence against insecurity",69 the media becomes the target of political ire either by 1) being accused of derogating the goals of the leader and unpatriotic obstructions; or by 2) being untrusted as propaganda that furthers the goals of the leader in power.

Numerous leaders around the world have used populism as a "medium of mass mobilisation" ${ }^{170}$ Recep Tayyip Erdoğan in Turkey, ${ }^{71}$ Hugo Chavez in Venezuela ${ }^{72}$ and Viktor Orbán in Hungary ${ }^{73}$ have all utilized communication tools to confirm the link between populism and the media. Nevertheless, the "causal connection was never explicitly articulated until recently, specifically in the United States with the rise of Donald Trump, ${ }^{74}$ who is a new leader among global representatives of populism. Aleksandar Vučić, the Serbian president still uses populism to try to promote himself as a democrat after a past political history allying himself with anti-democratic forces. The two politicians' biographies are considerably different from one another - Donald Trump is a self-proclaimed conservative businessman who started multiple attempts for the White House without having ever held any public office. Aleksandar Vučić, on the other hand, gained prominence in politics as a young, right-wing nationalist leader, who switched political orientations to a pro-western stance as a move to gain political power. Following Mazzoleni, Block and Negrine's claims, it may be added that both politicians have been deeply embedded with the media for decades: Trump as a reality show magnate keen on media spectacle ${ }^{75}$ and Vučić as the former Minister of Information (1998-2000), which "shaped him as a politician".76 Under Vučićs mandate (in 1998), which was under the authoritarian regime of Slobodan Milošević, a Law on Public Information was adopted in order to "defend the country".77 Yet, in effect, the law permitted "anybody to be sued for anything" laws. Therein, these two presidents of the US and the Republic of Serbia show similar treatment of their utilization of mass media in that they both originate from the top of a fixed pyramid of the political hierarchy.

Possessing previous media experience, both Trump and Vučić know how to amplify their messages. Apart from press conferences, Trump has repeatedly amplified his presence by taking to Twitter. Vučić, on the other hand, leverages his position through the unregulated media market of Serbia. ${ }^{79}$ On an almost daily basis, he is able to address the

\footnotetext{
69 Ibid., 300.

70 Turk 2018.

71 Ibid.

72 Block and Negrine 2017.

73 Csigo and Markovity 2017.

74. Block and Negrine 2017, 180.

75 Kellner 2016.

76 Mladenov Jovanović 2019, 62.

77 Ibid., 64.

78 Ibid.

79 See: European Commission 2019.
} 
entirety of Serbia by receiving coverage from all five of its nation-wide broadcast television stations. With their media experience, both men know how to address the messages to the audience. Should there be any contradictions in their statements, they are excused as stemming from the lack of understanding of the journalist or deflected with direct accusations that the press itself was lying to stir up discord and provocation. As journalist Tom McCarthy has noted of Trump: “The president's tactic of redirecting accusations of misconduct back at his accuser is childish, petty ... and surprisingly effective". ${ }^{80}$

\section{Populism as a Style}

In the age of anxiety, "populism" has come to be an oft used, broad term that requires clarification. While some authors use populism to "characterise certain political phenomena or brand competitors in a political conflict", ${ }^{81}$ most scholars define populism as an ideology. ${ }^{82}$ For Vlastimir Havlik, there are three references to understand populism:

The perception of the people and elites as homogenous groups, construction of an antagonistic and moralistic divide between the two groups and a view of the people as a moral sovereign and the need to restore the allegedly stolen sovereignty of the people. ${ }^{83}$

Mudde concurs, offering a "minimal definition" that explains populism as:

A thin-centred ideology that considers society to be ultimately separated into two homogeneous and antagonistic groups, 'the pure people' versus 'the corrupt elite', and which argues that politics should be an expression of the volonté générale (general will) of the people. $^{84}$

This paper will follow these concepts, but will not discuss populism as an ideology nor analyse the types of populism, as this analysis is not a comparison of the programs of populist leaders. The analysed samples of the two leaders may be closest to the pattern of the "nationalist populism with a charismatic outsider persona" ${ }^{85}$ though the paper will not discuss the argument that it is an ideology. Populism itself is perceived as a style that has no ideology of its own, which necessitates that it must pair with all forms of political ideology and is "almost always combined with one or more ideological features" 86 and has to borrow ideologies from other political platforms. In this regard, populism's "most common values are from other programs and ideologies (left and right populism)". ${ }^{87}$ For

80 McCarthy 2019.

81 Jagers and Walgrave 2017, 4.

82 Ibid., 4.

83 Havlik 2019,13.

84 Mudde 2004, 562; Mudde and Kaltwasser 2013, 149-150.

85 Rowland 2019, 356.

86 Atlagić 2017, 121.

87 Ibid.,121-122. 
the purposes of this paper, populism is used to denote a political communication style ${ }^{88}$ of "political actors that refers to the people". ${ }^{89}$ The political behaviour and political communication of populist leaders are that they tend to contain the following: "provoke the interest of the people, emotional charge, intention to shape the actions of the people as well as combination of elements of organized political persuasion". ${ }^{90}$ The populist message to the public is one of "I listen to you because I talk about you".91 The populist also accuses the media of being its opposite: "I do not listen to you because you are against me".

Populists, as political representatives, personalize politics by using specific communication tools and "persuasive techniques of promoting personal examples based on psychological principles" 92 in order to "shape the behaviour of the people." ${ }^{93}$ Populism relies on conventions that sow divisions among communities, which leads to a paradox as populist leaders try to communicate but must always resort to compulsive categories of "polarisation on good and/or bad", ${ }^{94}$ us and/or them, current and/or previous. Populism takes an "anti-establishment stance and stresses the (ideal) homogeneity of the people by excluding specific population segments." ${ }^{95}$ Such exclusions are not the only criteria when analysing the communication style of populist leaders. "Anti-elitism" and "anti-establishment" cannot stand alone as exclusive criteria and the exclusive trait of populism as "many radical political movements in general are driven by anti-elitist attitudes" ${ }^{\prime 96}$ as well as that "most scholars consider anti-elitism as a central feature of populism". ${ }^{97}$ These exclusions therefore lead to the development of an "atmosphere of animosity and mistrust toward political elites"98 Populist attitudes toward political elites and intellectual elites therefore naturally form along these lines where the "enemy" is reflected "in the previous authorities (D. Trump, A. Vučić) or some other social groups.". ${ }^{99}$ Such excluded groups could be any group which is perceived as a threat to the system. It may not only be members of the political elite itself, but the "media (media tycoons, journalists, etc.), the state (administration, civil service), intellectuals (universities, writers, professors) or economic powers" ${ }^{100}$

88 Jagers and Walgrave 2007; Atlagić 2017; Block and Nagrine 2017.

89 Jagers and Walgrave 2007, 3.

90 Atlagić 2017, 125.

91 Jagers and Walgrave 2007, 4.

92 Atlagić 2017, 124.

93 Ibid., 124.

94 Ibid.

95 Jagers and Walgrave 2007, 1.

96 Ibid.

97 Ibid., 4.

98 Stanley 2008, in Atlagić 2017, 120.

99 Ibid.

100 Jagers and Walgrave 2007, 5. 
The enemy which is "external to the people"101 may also be among them. Journalists are one case in point as they may be designated enemies of the people. Hence, populism in the media is shown to be "the most evident effect on the transformation of the political language into spectacle."102 Populism and "media populism" complement each other and, at the same time, derogate the substance of the two professions (i.e. of being a political representative or a media representative/journalist). Both support each other - the leaders offer what the media "needs" while the media produces new populist content sharing: "anti-elitist, aggressive, emotional speech which breaks the boundaries of political correctness, controversy and conflict, charismatic and highly personalized leadership". ${ }^{103}$ Arguing an issue which is shaped by controversy and demonization may be followed by intimidation of the other. This is articulated with a specific style, an "act of speech" using the:

...words, signs, and images - forms of communication - to connect with the people (the disenchanted, disadvantaged, aggrieved groups mentioned) and demonize the Other, usually the centre-ground elite, or the establishment. ${ }^{104}$

The political communication of populist leaders is coloured emotionally. Their speeches and the messages they address are intended to engage emotions. The populists use the affective logic in which "feelings precede intellect"105 offering "perceptive argumentation (argumentum ad oculum), pseudo arguments (insinuation and labelling and personal disqualification (argumentum ad hominem)". 106

This style of communication feeds on divisive issues, aggressiveness, controversy and conflict. By its frequency, it is already perceived as a "new normal" ${ }^{107}$ As such, this "new normal" has become a model in many countries around the world. Populist leaders draw the legitimacy of their behaviour based also on the frequency of the phenomena.

Like other populist leaders, Donald Trump is keen on dividing, following "principles" of the "real" part of society and the Other in a spectrum of race, gender and identity. ${ }^{108}$ These divisions drive its potential from the division of Us and Them, aliening the Other, perceiving the media outlets as one of Them, as "he feels attacked by media elites"109 (see the "dividing" criteria below).

\footnotetext{
101 Ibid., 4.

102 Atlagić 2017, 134.

103 Ibid., 133.

104. Block and Negrine 2017, 180.

105 Atlagić 2017, 125.

106 Ibid.

107 Block and Negrine 2017, 190.

108 Rowland 2019, 349.

109 Rowland 2019, 357.
} 
Following these principles, he is keen on arguing with his enemies and having the opportunity to address the political elites and media outlets at his press conferences. In most of his speeches (reflecting an entire message or focused on an "aspect of the dystopian landscape", ${ }^{110}$ elites and the media are "omnipresent villains whose corruption allowed the Other to undermine the nation".111 As he has had opportunity to "speak" with the media at press conferences, he addressed the media outlets he doesn't like which are perceived as representative of the corrupted elite. Expressing "anger against elites, the media, immigrants (which plays) a crucial role in Trump's rhetoric and success",112 Trump is in a constant polemic and disagreement with its representatives (see the "arguing" criteria below).

The speeches of President Trump are coloured emotionally, as his populism "does not serve an epistemic but rather an affective function", ${ }^{113}$ provoking an "emotional response". ${ }^{\text {"14 }}$ His language is simple, low-graded and colloquial, addressing a wider audience. ${ }^{115} \mathrm{His}$ speeches promote "political anti-intellectualism". ${ }^{116}$ The rhetorical pattern of othering and his policy serve to "generate additional fear" 117 and the purpose of the fear is "internal intimidation as a basic mode of social and political control" (see the intimidation criteria). ${ }^{118}$

Donald Trump uses the media (and media platforms) to address his messages, attack the "enemies", argue with them and bond with his voters. As he uses the social networks frequently, he presents himself as a representative of open and direct communication with citizens, "testing every aspect of free speech, beginning with the importance of the truth" ${ }^{119}$ At the same time, his speeches at rallies and press conferences are resistant to fact-checking and argumentative critiques and even have "little influence on his affective relationship with core supporters". ${ }^{120}$ Faced with fact-checking, arguments or questions, he feels attacked as he had attacked "the out of touch media elites" ${ }^{121}$ which frequently alter into a form of "an Other to hate, elites to blame, and a hero to idolize"122 (see the "open for speaking, not to debate" criterion).

\footnotetext{
110 Ibid., 359.

111 Ibid.

112 Rowland 2019, 347.

113 Ibid., 346.

114 Ibid.

115 Kayam 2018, 86.

116 Ibid., 76.

117 Goodman 2017, 152.

118 Robin in Goodman 2017, 152.

119 Caplan 2018, 25.

120 Rowland 2019, 346-347.

121 Ibid., 357.

122 Rowland 2019, 369.
} 
Even though he is a representative of business elites in the US, Trump uses his populist rhetoric to present himself as a representative of the voiceless against "the immigrants, minorities, and liberal elites who had wrought an American carnage". ${ }^{123}$ His "anti-elitist populism", based on the "frustration expressed against elites as the others", is combined with "excluding populism - the exclusion of dangerous others, such as immigrants". ${ }^{24}$ In the case of the media, his anti-elitism is strongly focused on elite media outlets (see the "anti-elitism" criteria).

\section{Methodology}

This paper seeks to analyse the specific style of the political communication of Donald Trump toward journalists and to try to find similarities in the pattern of this communication model with that of the Serbian President, by answering the research question: What are the similarities in the style of political communication between Donald Trump and Aleksandar Vučić? The main hypothesis is that: The populist political leaders the US president Donald Trump and Serbian president Aleksandar Vučić have the same style of political communication, which is mostly reflected through their attitude toward journalists. The hypothesis will be operationalized with the following analytical categories. First, this communication style consists of labelling journalists on the basis of the media outlets they work for or by arguing on a personal level with reporters contributing to a division between "friendly and unfriendly media". Second, the style insists on the existence of fake news when trying to avoid giving a clear and direct answer to a journalist's question, and in this, the leaders are abusing their position (as representatives of all).

The approach in this article will be to analyse twelve press conferences of the two leaders, six for each of them, from 2016 up to 2019, following four steps. In the first section, the article will detect the unique communication style of Donald Trump using five criteria derived from the theoretical framework of the populist communication style. These five criteria will be applied and explained in a case study of a significant, extreme conference at the White House about the midterm elections (7 November 2018). Then, these five criteria will be also applied to the rest of the sample of Trump cases (The press conferences of the 16 February 2017; 1 October 2018; 21 August 2019; 25 September 2019; 2 October 2019). These press conferences are chosen for their specific interactivity, the existing tension or conflicts that are expressed between the US President and the journalist for a media outlet. That does not mean these are the only conferences with such conflict, but the six of them were chosen to represent the president's particular political communication style.

In the following section, the article will analyse the political communication of the Serbian president Aleksandar Vučić. The same five criteria will be applied to the extreme,

123 McCoy, Rahman, and Somer 2018, 30.

124 Elçi 2019, 390. 
significant case of the press statement in confrontation with N1 reporter (18 October 2018), a sample which will help to demonstrate the style of communication that was used. The five codes will be also analysed in the rest of the chosen cases (24 January 2017; 24 February 2017; 16 January 2018; 23 March 2019; 26 April 2019). ${ }^{125}$

Drawing upon the literature discussed above, Trump's style of political communication is characterised by the following five criteria. The first criterion is the "dividing issue" as the leader is keen on dividing between the good and bad (people, journalists, media outlets) with the attitude that good supporters behave kindly toward him/his policy and bad supporters do not. The second criterion is the "arguing issue", as the leader is keen on arguing about various subjects, perceiving questions as attacks, and is in constant defence by offending those seen to be in disagreement. The third criterion is the "intimidating" issue, explained as being keen on labelling and referring to something personal or private. The fourth criterion is being "open to speaking but not for debate", meaning seemingly inclusive in communication, but factually exclusive to those he shares an opinion with. The fifth criterion is named "chosen by people, anti-elitist", by highlighting the perception that the leader has been chosen by the voiceless, supported by the voiceless which bolsters his legitimacy, in contrast to an elitist, contributing to the division of elitist/anti-elitist, intellectual/anti-intellectual.

The analysis is based on twelve press conferences, including media statements, chosen for their unique interactivity, tension and conflict with media representatives. It is important to highlight the differences in their communication with the media - while the Serbian president makes statements almost every day, the American president is more inclined towards communication over Twitter, paralleled with press conferences. All Trump's press conferences that are analysed below are taken from the official transcription of the White House (the White House briefings). The names of the journalist were used only in cases where it was necessary for understanding the context, as the official transcriptions do not contain the name of the journalist and media outlets. All the transcriptions in the Serbian case were made and translated by the author of this article. 


\section{Donald Trump's Communication Style}

The significant case that will be used in the example of Donald Trump is the press conference at the White House about the midterm elections (7 November 2018). This conference can be divided into three points: arguing with CNN's correspondent Jim Acosta, replying to PBS NewsHour reporter Yamiche Alcindor and commenting on NBC reporter Peter Alexander and April Ryan, National Urban Radio Network's White House reporter.

On the first point, CNN reporter Jim Acosta asked President Donald Trump about the migrant caravan that Trump had classified as an "invasion". Acosta questioned why the President classified it as an invasion and also asked if the President demonized the migrants. Trump answered:

CNN should be ashamed of itself, having you working for them. You are a rude, terrible person. You shouldn't work for CNN. You are a very rude person. The way you treat Sarah Huckabee (ed. White House press secretary) is horrible. The way you treat other people is horrible. You shouldn't treat people like that. ${ }^{126}$

After the White House staff took the microphone from Acosta's hand, reporter Peter Alexander from NBC, challenged the president's characterization, calling Acosta a "diligent reporter". Trump cut him off: "I'm not a big fan of yours, either". President Trump then turned back to Acosta, who was still trying to ask a question (about the Russian investigation) and said: "When you report fake news which CNN does a lot, you are an enemy of the people". 127

At the same conference, Trump accused PBS NewsHour African-American reporter Yamiche Alcindor for asking a "racist" question when she questioned whether the president had used the word "nationalism" in the sense of the meaning of "white nationalism". Trump answered: "I don't know why you'd say that, that's such a racist question". ${ }^{28}$ Alcindor asked: "There are some people who say that now the Republican Party is seen as supporting white nationalists because of your rhetoric, what do you make of that?". 29 Trump answered:

\footnotetext{
I don't believe - well, I don't know. Why do I have my highest poll numbers ever with African Americans? Why do I have among the highest poll numbers with African Americans? I mean, why do I have my highest poll numbers? That's such a racist question. Honestly, I mean, I know you have it written down, and you're going to tell me. Let me tell you: It's a racist question. ${ }^{130}$
}

Trump also added: "Excuse me. But to say that - what you said is so insulting to me. It's a very terrible thing that you said". ${ }^{131}$ At the same conference, Trump told the National Urban Radio Network White House correspondent April Ryan to sit down when she attempted to ask a question. 
This conference was an extreme and significant example of the five criteria which characterize Trump's political communication. The dividing issue is represented in Trump's willingness to declare a journalist/media outlet to be an "enemy of the people" (CNN case) and is an example of being either for America/Trump or anti-America. His communication is followed by his strong division based on the perception of journalists as being either friendly or unfriendly. All three examples show a willingness to argue with media representatives including his expression of power, which is shown by taking away the microphone from a journalist's hand by a White House staff member. The intimidating issue is seen in the argument with CNN reporter Jim Acosta, which started with Trump insulting the reporter on a personal level, using language like "bad, horrible person", and by telling the NBC reporter he was "not a big fan of his, either". This also contributes to the dividing issue, as "not being someone's fan" means being an "unfriendly journalist". In parallel, giving journalists the opportunity to speak and to ask questions doesn't mean they will have an opportunity to answer and follow up, which accurately correlates with the lack of debate, related to the "open to speaking but not for debate" issue. The "chosen by people, anti-elitist" issue is seen in Trump's reply to the PBS reporter, which consisted of the clear statement of being supported by people (from African-Americans to the "white nationalists in the Republican Party") when the question was asked, while Trump's questioning of this issue resulted in his labelling the reporter as racist.

Trump's division, based on the line against-me/fake and pro-me/true, can be found in almost every case which was chosen for the sample of analysis. His dividing issue is strongly pointed against $\mathrm{CNN}$ and similar media outlets that support Democrats, and the president does not hesitate to point to this out in his speaking points: "We would be a far greater when we don't have the CNNs of the world, who are corrupt people".132

The arguing issue, which is widely present in his press conferences, is complemented with his disqualification of journalists/media and his use of accusation without offering any evidence. The constant accusation that journalists disseminate fake news (see the first case) is followed by the accusation that they are dishonest, unprofessional or corrupt:

People like you and the fake news media that we have in this country. And I say, in many cases, the corrupt media - because you're corrupt. Much of the media in this country is not just fake, it's corrupt. ${ }^{133}$

Besides all the divisiveness that he contributes to, dividing the friendly and unfriendly, pro- and anti-America reporting, enemies and allies, in addition to his expressed and direct arguing with journalists, Trump's political communication includes the intimidation of journalists on a personal level. His desire is to "find a friendly reporter", 134 on the basis: "Wait, let's see, who's - I want to find a friendly reporter. Are you a friendly re-

\footnotetext{
132 White House 2019b.

133 Ibid.

134 White House 2017.
} 
porter? Watch how friendly he is. Wait, wait - watch how friendly he is. Go ahead".135 The intimidating issue based on Trump's perception of what a reporter looks like had its roots in Trump's candidacy for president. For example, during the electoral campaign, Trump pointed out ABC News reporter Tom Llamas and called him "a sleaze", told CNN reporter Jim Acosta "he is real beauty", called Fox News host Megyn Kelly "a bimbo" and characterized NBC's representative Katy Tur as "little Katy, third-rate journalist". ${ }^{136}$

Personal altercation is seen in remarks such as "by the way", speeding up the asking of questions, interrupting by teasing "should I let him speak?" or comments like "She's shocked that I picked her. She's in a state of shock,"137 followed by the laughter of his cabinet. These are typical communication tools that help undermine the journalist's position and right to ask. Personal insults come as a differentia specifica of Trump's political communication and contributes to lowering the respect towards the targeted journalists and the media itself. The example below shows this more precisely:

President Trump: Okay, question. Yeah. Go ahead. Sure. She's shocked that I picked her. She's like in a state of shock.

Reporter: I'm not. Thank you, Mr. President.

President Trump: That's okay. I know you're not thinking. You never do.

Reporter: I'm sorry?

President Trump: No, go ahead. ${ }^{138}$

Trump is keen on debate, but without facing any rules of argumentation and debate. Even though he is in a position of supremacy in the speaker's place in front of the camera, he will stop the journalist when he finds it appropriate or by telling him or her to "sit down"139 or be "quiet, quiet, quiet". ${ }^{40}$ His relations with the media are inappropriate on several layers. Even though he came from the media industry, he finds the media outlets to be "liars" and he doesn't hesitate to express that even from the public stage of the White House. The case of a Jewish journalist who tried to ask a question shows his lack of regard for basic media rights:

Journalist: What we are concerned about, and what we haven't really heard be addressed is an uptick in anti-Semitism and how the government is planning to take care of it. There have been reports out that 48 bomb threats have been made against Jewish centers all

\section{Ibid.}

136 See more: Byers and Diamond 2016.

137 White House 2018a.

138 Ibid.

139 White House 2018.

140 White House 2017. 
across the country in the last couple of weeks. There are people who are committing antiSemitic acts or threatening to...

President Trump: You see, he said he was going to ask a very simple, easy question. And it's not. It's not. Not a simple question, not a fair question. Okay, sit down. I understand the rest of your question. So, here's the story, folks. Number one, I am the least antiSemitic person that you've ever seen in your entire life. Number two, racism - the least racist. Quiet, quiet, quiet. See, he lied about - he was going to get up and ask a very straight, simple question. So, you know, welcome to the world of the media. But let me just tell you something - that I hate the charge. I find it repulsive. ${ }^{141}$

But, just for a comparison, Trump's perception of a "friendly" and "nice" question was one that referred to the positive aspects of the activities of his spouse Melania Trump.

Journalist: And she does a lot of great work for the country as well. Can you tell us a little bit about what First Lady Melania Trump does for the country? And there is a unique level of interest in your administration, so by opening the White House Visitors Office, what does that mean to you?

President Trump: Now, that's what I call a nice question. That is very nice. Who are you with ${ }^{142}$

In light of the context of Trump's candidacy, it might be said that he is the first US president with such an anti-campaign in the strong media such as the New York Times, the Washington Post and CNN, especially compared with the relation that those media had with President Obama. But he relies on Fox News, pulling his legitimacy from the Fox media outlet and the influence it has with Trump's base. But, although becoming the president of all Americans, he has continued his policy of arguing with the "elite" media and accusing them of spreading fake news. Making comparisons between the fake and unwanted is an additional point that has shaped his political communication, by labelling the unwanted media market as fake news, ${ }^{143}$ both at press conferences and on his Twitter account. He is free to express his comments, but he is open only for limited debate. His anti-media attitude matches with his anti-elitist attitude and both are present in almost every segment of his remarks to the audience. In a populist's way, he likes to point out his excellency in a variety of occasions (even in the presence of other foreign officials), emphasizing that the media has created the fake picture of himself.

President Trump: I don't like the concept of releasing calls because when a president or prime minister, or a king or a queen, calls the United States, you don't like to say, 'Gee, we're going to release your call to the fake-news media, and they're going to make you look like a fool'. What happens is, it's hard to do business that way. You want to have people feel comfortable. So, I hated it, but you folks were saying such lies, such horrible things about a call that was so innocent and so nice. In fact, Lindsey Graham said to me, when he read it - it was very interesting. He's a good man. He's a smart man. He said, 'I

\footnotetext{
$141 \quad$ White House 2017.

142 Ibid.

143 White House 2018.
} 
can't believe it. I never knew you could be this, really, nice to a person'. He said, 'I cannot believe it. You were so nice. I didn't think you had that in you to be so nice. I was nice. I'm nice to a lot of people. People don't understand that. But I was. But he was shocked that it was such a nice call. There - he said, 'There is nothing here' And all fair people say the same thing. ${ }^{144}$

These 6 press conferences show the unique style of Trump's communication that is based on (at least) these five criteria. It is a divisive communication that alienates the specific media outlets (but not only them), with strong intimidation towards the journalists and a tendency to argue emotionally rather than to offer relevant argument. His rhetoric is colloquial, with simple language, but his messages are directly addressed to critique media outlets as the representatives of the anti-Trump base. This approach goes beyond an institutional type of communication between the political representative (of the nation) and a particular group, forcing its exclusion while eroding democratic principles.

\section{Aleksandar Vučić's Communication Style}

To analyse the communication power of Vučićs speeches and its correspondence with Trump's type of political communication, the article will first analyse an extreme, significant example as in Trump's case, and then continue with pattern codes found in the rest of the case studies. On one occasion of his regular conferences and more, when giving press statements, Vučić focused his attention on the subject of the conference and then discussed all other topics. The statements after "official events" are frequently used to send messages to his supporters and his "enemies" (the opposition, journalists, or representatives of other countries). In a great number of cases, the press statements after a particular event gain more publicity than the event itself.

President Vučić: How many times have you, Miss Stojisavljević ${ }^{145}$ or your colleagues from TV gone to the rooms of Vuk Jeremić ${ }^{146}$ to cry for a statement by Milenko Jovanov. ${ }^{147}$ So you didn't go to cry to the Informer, ${ }^{148}$ because Dragan Đilas asks to arrest the Informer's editor in chief?

Journalist N1: Please, let me beg you two things: First, not to put pressure on journalists in public service like you just did. Second, to start to refer to our media house by our name, N1. For months, you have called us 'Đilas's and Šolak's TV'. Šolak has part ownership in N1, but Dragan Đilas has nothing to do with our media outlet. So, I'm asking you to treat us professionally as we treat you. Is that okay?

\footnotetext{
144 White House 2019a.

145 A journalist from RTS, public service.

146 A leader of the opposition party, married to Nataša Jeremić, ex. RTS anchor and editor.

147 Ruling party member (Serbian Progressive Party) who accused that Nataša Jeremić that she "mangages the entire drug market in Serbia". Nataša Jeremić sued Milenko Jovanov, the Serbian Progressive Party and its leader Aleksandar Vučić in court.
}

148 A pro-government tabloid. 
President Vučić: Do you have a question?

Journalist N1: Yes, I do. If Serbia finds itself paralyzed because Kosovo forms an army, what will be Serbia's response?

President Vučić: I was trying to behave professionally despite the fact that you have never been professional. It is the uncomplimentary word referred to you, from my side. To you, the direct representative of Dragan Đilas. Do you want to forbid me to think? Who are we? Who has a right to tell me what I may do and what I may not - or are you going to open a 'commission for hanging', because I don't think the same as you do? About Šolak and Đilas, you are right, there is no written proof that he is the owner, officially on paper. He is owner of Direct Media and a company in Bulgaria, which was bought by Šolak. They are owners of a company on Malta, also. Is this the truth? It is! Just to help people understand who is lying and who tells the truth. Šolak and Đilas are together in all the businesses they do. They are selling to one another [...] Did Šolak pay 10 million euros to buy a building from Đilas? But you don't like to talk about facts. But you like to treat me like a punching bag because I don't have the opportunity to defend myself on your TV. When I have the opportunity to tell the truth - the truth suffers! I'll call you what you want, but I would not miss the opportunity to say that it is Šolak's TV with Đilas' max political influence. The people will decide. ${ }^{149}$

These cases will be analysed in a same way as Trump's extreme case was. When the dividing issue criterion is concerned, we see that Vučić made a clear distinction between "the supporters" of N1 as a corrupt elite and himself. He also made a distinction between a media outlet and journalist as a "liar" and himself as the one who speaks the truth. He underlined the people's will to decide to support the truth contrary to the "lies published by media outlets". The president first openly argued with an RTS journalist. Later, he accused an N1 reporter of wanting to "treat him like a punching bag", to form a "commission for hanging", and of "not telling the truth". This falls under the criteria of the arguing issue, but also slips into the intimidating issue. When he stresses the (unproven) evidence that the RTS reporter "cried in the office of the opposition leader", he derogates her position. At the same time, his references to the journalist as unprofessional and coming "direct from the office of the opposition" are personal attacks which correspond to the intimidating issue criteria. The fourth criteria can also be applied as the president stressed that he was open to being asked but instead of answering, he offered accusations without valid proof, calling on the people "to believe" him. Pointing to the will of the people to decide who is telling the truth and stressing that he is "happy because neither the Americans, nor Šolak nor Đilas decide what he should think" are examples of the populist pattern "chosen by people" and the "anti-elitist" criteria.

There are a lot of examples here that fall under the dividing issue, in this highly polarized media scene. Vučić also perceives media outlets as either friendly or unfriendly, but in the local context one must keep in mind the disproportionate nature of the coverage - when obligated to promote all sides of the process, the public media service in its news programs not only promotes the position of the ruling party and its leader, but

149 Press statement, Belgrade, October 18, 2018. 
they are constantly accused of not promoting it appropriately (see European Commission Report). The national airwaves are used by "friendly" media outlets (according to a nontransparent ownership that has lasted for almost a decade), while several research outlets (BIRN, KRIK, Istinomer) and N1, a cable operator limited in its distribution, is perceived as unfriendly. The tabloids also maintain a pro-government orientation, while the news magazines, although with limited coverage, promote a critical media orientation. All this disproportionate coverage comes from an unregulated media market that has lasted for decades, with unclear media ownership and a strong media connection with the state or the ruling party's financing.

The next example of Vučić's sarcastic reply to the media confirms this:

Everyone has to be like N1. It is the only example of professional journalism; if they are not like N1 just shut it down. Shut down Prva TV, Pink, B92, all! Only theirs is good. Luckily, I have never been there, thank God. ${ }^{150}$

The division issues are obviously prima facie, but they are also confirmed in almost every press conference where the president, answering a question, refers to "your supporters", or "the ones you like" willing to criminalize the connection between financiers and media outlets, without offering any proof from an institutional investigation. When, in October 2018, the Serbian government spent seven days in the south of Serbia, workers of the failed state companies in Niš were promised that their salaries would be paid to them. Five months later, the journalists of Istinomer and N1 Television asked the president why this promise was not fulfilled, but before his answer, he again labelled them foreign mercenaries who advocated for the interests of "those of yours": "The companies broke down in the time of people you are supporting". ${ }^{151}$ When asked by the journalist from Istinomer why he constantly labelled and humiliated journalists who dared to ask him questions, Vučić replied: "You humiliate me by interrupting me constantly and because you want to make a case. You came from Belgrade to do that; you will not succeed in that". 152 This was followed by personal references: "Why are you annoyed - it's not going well for the ones you support?" When the reporter asked the president why he "humiliates journalists who ask a question" he answered: "You humiliate me by frequently interrupting. You want to make a case. You came from Belgrade to do that". ${ }^{153}$ The dividing issue is a permanent feature and incorporated into almost every answer related to "unwanted" media outlets.

President Vučić will say that the media outlet "is lying","154 that it bases its media agenda on anti-Vučić policy, ${ }^{155}$ but he will also use the dividing issue when he wants to escape an-

150 Press statement, Novi Sad, March 23, 2019.

151 Press statement, Niš, February 24, 2017.

152 Ibid.

153 Ibid.

154. Press statement, Belgrade, October 18, 2018.

155 Ibid. 
swering the question. As in Trump's case, the permanent reflection on the media ground, asking a journalist to put himself in his shoes and to decide is a useful tool to avoid an answer and pass on to the irrelevant. When a journalist asked him to comment on an old picture of his Minister of Health Zlatibor Lončar with the criminal Dušan Spasojević, involved in the assassination of PM Zoran Đinđić, the president answered:

What do you think about the photo of the ones you support who sell and distribute drugs to our children? And these have become the main bosses of their campaigns, you support them every day. ${ }^{156}$

As was obvious from the previous examples of the dividing issue, the arguing issue is dominantly manifested in most of his press statements and all statements in the sample. As in Trump's case, the journalist was accused of constantly interrupting: "Stop interrupting me, don't be rude, you did it five times", 157 even as his answer might divert to the irrelevant within his extended media statements on a daily basis. A strong journalistic attempt to get an answer to a specific question might turn into a reflection or accusation for interrupting. Arguing the issue is widely present, but in most cases, it would be hard to understand without the whole context, because most of the answers consist of accusations, without referring to specific cases and offering specific proofs. The answers and messages are difficult to understand even for the journalist, if they are not completely aware of the context which is made of stories published in tabloids and on pro-government commercial TV. Messages that are sent during the debate with the journalist or separately are "surprisingly effective" as Tom McCarthy said while explaining Trump's argumentation: "When accused of this, or revealed to have done that, Trump simply blurts 'she did it' or 'he's guilty', whatever the charge may be".158

When comparing the intimidation issue found in Trump's rhetoric, there are differences in the type of communication between the two presidents. While Trump uses his position to humiliate journalists even on a personal level, Vučić does not insult journalists in the same way. He argues with them or underrates the media outlet's journalist for their work:

Can you do me a favour. Please take your gossip and rumours to my late grandma Višnja, about your alleged suspicions to the police and tell them. ${ }^{159}$ (on the question of the murder of the opposition leader in Kosovo, Oliver Ivanović).

He rudely refers to a journalist's work by saying, "stop flaming"160 or "you made it up",161 even when the journalist quotes his previous statements. But, contrary to Trump's tendency to intimidate and offend on a personal level, Vučićs political communication does

\footnotetext{
156 Press statement, Belgrade, January 24, 2017.

157 Press statement, Niš, February 24, 2017.

158 McCarthy 2019.

159 Press statement, Belgrade, January 16, 2018.

160 Press statement, Belgrade, March 23, 2019.

161 Press statement, Belgrade, May 24, 2019.
} 
not contain such examples. Vučić presents himself as the personal protector of journalists. For example, when the government-friendly Studio B reporter Barbara Životić was verbally attacked because of her biased reporting, the president promoted himself as her protector saying: "Barbara is a lovely kid, say hello to her, she is a young child".162

Vučić, in theory, does not refuse to answer the media's questions (third code, open for questions); more precisely, following the examples that were the subject of this analysis, he permits all media outlets to ask questions but does not offer relevant answers. In most cases there is no debate, the answers are reflections on the media content or arguing with media representatives. He presents himself as a representative of "polite people in Serbia" also calling party members "to be polite while answering the media even when being attacked by the media", 163 because there is no such thing as a "cheeky, ruthless question", just a "stupid answer", ${ }^{164}$ but their behaviour shows the opposite. He frequently points out that he will answer all journalists' questions, which he does, but that doesn't mean there will be a coherent answer to every question. He gives an opportunity to the journalist to ask the question, but he doesn't reply with an answer to the question, if he doesn't want to. But it should be kept in mind that media outlets are not a coherent group. Pro-government outlets have made an effort to contribute to these divisions, blindly accepting whatever the government does, not only by expressing the opinion in the "factography" 165 or by sharing biased attitudes and personal emotions when reporting, but also in accusing the other outlets and other non-likeminded of creating diversions against the state.

These relations contribute to undermining the journalists' position, but the strong division between "Mine" and "Yours", put the journalist in a dangerous position in the fragile Balkan political landscape where escalation of violence is possible on a daily basis, especially in tense regions such as Kosovo. On the decision that the Serbian list sent from Belgrade, ${ }^{166}$ was not permitted to participate in Kosovo's election, the president accused a journalist, positioning them on the side of the "others", even though they are already in a dangerous position working besides two unregulated systems, between Belgrade and Pristina:

But they are against the idea of the Serbian list winning the elections. They have invested a lot of money to destroy the Serbian list and divide it from Serbia. Look how much money they invested in creating the media in the north of Kosovo. How many foreign media were created, Westerners created them in the north of Kosovo, only to destroy the reputation of the Serbian List. See all the campaigns that are being conducted for the criminalization of northern Kosovo. And they did nothing [...] Organizing a media agency network, especially in the north of Kosovo, millions of dollars are being paid and

162 Press statement, Belgrade, December 9, 2018.

163 TV Happy 2018.

164. Ibid.

165 Jevtić 2016, 57.

166 The list of the Serbian representatives who participated in Kosovo's election, instructed and supported by the Serbian officials from Belgrade. 
this becomes your main information which providers in Central Serbia, and in many other places directly paid off, just to overthrow the unity of the Serb people in the north of Kosovo and Metohija and in other parts of Kosovo and Metohija, too. ${ }^{167}$

In such a media scene, in a poor and unregulated media industry market, ${ }^{168}$ the reflections of the president's behaviour are deeper and invasive not only to the media, but to the society. It is not only part of the communication strategy but a strategy directed at non-like-minded in every pore of society which further leads to accusation and division at all levels. Like Trump, Vučić promotes himself as a president with high support, chosen by the people. His anti-elitism expressed in media statements ("Westerners created the media", ${ }^{169}$ glad not to be instructed "by Americans" ${ }^{170}$ ) are also expressed in his editorial in the Politika newspaper, with the headline "Elite and plebs" ${ }^{171}$ in which he addresses those who criticize him:

The last days in the ubiquitous campaign of belittling everyone who thinks differently from those in Serbian society, who have imagined that, for some reason, they belong to an elite, thinking, socially and mentally emancipated stratum of society. ${ }^{172}$

This article contributes to extreme divisions in Serbian society, marking and expressing all the differences, creating irony and insulting the "elite" from the President's point of view.

\section{Conclusion}

Following global trends in a post-truth era in all aspects, it is obvious that the truth, as Daniel Boorstin said, "gave way to faith", ${ }^{173}$ so frequent lies and semi-lies could be easily placed as official narrative. Instead of Chomsky's appeal to "question everything”, journalists are put in the position to not ask questions about anything, because they might be accused of subversion. The examples of both extreme cases represent the way the two leaders treat the media as such. The extreme cases may stand alone in showing patterns of populism in the political communication of the two presidents, but also similarities in their communication styles. Even though journalists are obliged to "recognize a special obligation to serve as watchdogs over public affairs and the government and to seek to ensure that the public's business is conducted in the open, and that public records are open to all", ${ }^{174}$ none of these criteria is being respected, permitted or possible in any of the examples outlined here.

\footnotetext{
167 Press statement, Belgrade, April 26, 2019.

168 Milosavljević and Polar 2019.

169 Press statement, Belgrade, April 26, 2019.

170 Press statement, Belgrade, October 18, 2018.

171 Vučić 2019.

172 Ibid.

173 Boorstin 1992.

174 Society of Professional Journalists 2014.
} 
The analysis of communication models of the US President Donald Trump and the Serbian president Aleksandar Vučić reveals the similar communication pattern, shaped in the particular contexts of each country. Both presidents are keen on the dividing issue, creating the perception of friendly and unfriendly media, but more, all these media perceptions impact a society as a strongly divisive issue. Being pro-government is equated with being a patriot, pro-state. Being critical is equated with needing to be instructed and representing an anti-state element that is strongly against of everything that the president or government does (using pro-government in the Serbian case refers not only to Government representatives but to the strong political area that the president makes decisions on). The strong polarization of the society is followed by strong controversy, which both presidents are keen on maintaining. They use most of their opportunities to argue with the press - President Trump at his press conferences followed by strong and frequent communication on his Twitter account, while President Vučić uses his power to be broadcasted almost every day in his press statements on different occasions. The press conferences at the White House are limited to several questions that might be asked, so the journalists that have an opportunity to ask the question feel "selected" and "chosen". In the Serbian case, the majority of the journalists at the ad-hoc press conferences/statements have the opportunity to ask a question, as the statements last until the last question, in most cases. This does not mean that all the journalists will get a proper answer, as the answer might be diverted to the irrelevant. In both Trump's and Vučić's cases, the critical media outlets are accused of being instructed - by "foreign" forces or by the "opposition" in the Serbian case, which corresponds to Trump's "enemy of the people".

Following the criteria on the intimidating issue, there are visible differences within this communication model. While Trump would label a journalist on a personal level, as being a "terrible person" or "sleazy", president Vučić would not permit himself to do so. As he is a former nationalist now willing to foster the EU accession process, he is trying to present himself as calm and not affected by the journalist's questions, even though his descriptions of media outlets and non-like-minders correspond with Trump's insults. Vučić argues with journalists, telling them that they are instructed, that they lie and fabricate their stories even when they quote his own words. He provokes journalists for "being annoyed", "being profiteers of the foreign or criminal-opposition money", but he does not deliver personal insults the way Trump does. Yet these two post-truth politicians use the same tools, guided by the same pattern, such as asking journalists to put themselves in his shoes or to "advise" him what to do.

As has been said, there are differences in the opportunity to ask (from press conferences to press statements) and getting a relevant answer. Those circumstances are based on differences in the two countries' political systems, the media market and also in the media culture. In the end, as the last criterion, both presidents have a populist self-perception which assumes that they are "chosen by the people" in a struggle to fight against a previously unfair system shaped by corrupt or limited-minded political elites, even though both of them are actually representatives of the political and/or business establishment. 
Even the presidents use a similar populist communication model, the main difference is that Donald Trump is more oriented toward intimidation on a personal level than Aleksandar Vučić, according to the analysed sample. The differences in their communication pattern are shaped by different personal backgrounds, but also by the media landscape and the rule of law. The populistic pattern of Vučić's communication, directed at a fragmented, corrupted, controlled and weak media market, indicates the weaknesses of local democracy. Hence, this research might be used for other comparisons of communication models of populist leaders in the Western Balkans region, as well as in CEE and throughout the rising right-wing populism found in Western Europe. In addition, this paper might be useful for research that seeks to analyse the process of democratization and anti-democratic development in the region, as well as the success of the EU accession monitoring process, following the media as a relevant indicator of democratization.

Our representatives at the highest level contribute to divisions globally and locally, deepening the gap among the media as well as among the citizens. This does not mean that media outlets today are the best that they could be. But, the attitude towards their media watchdog role is something which should not rely on personal whim, but be institutionally framed, indicating that leaders show their limited capacities and a lack of awareness of the institutional framework.

In spite of their personal attitudes or whether they are satisfied with the professionalism of the media, political leaders do have a responsibility toward journalists, both as guardians of the public interest and as members of the community they represent. The perception of journalists as enemies of the system can lead to a particular reluctance in society that allows a level of arbitrariness at all levels. If we look back on McCarthy, the fear of communists is embedded in their constant accusations, very similar to the fear of journalists, while accusing them of defying the public interest. A system that permits such arbitrariness is a system that can easily slip into authoritarianism. 


\section{References}

Atlagić, Siniša. 2017. "Populizam i politička komunikacija." In Populizam, edited by Zoran Lutovac, 119-131. Beograd: Institut društvenih nauka, Centar za politikološka istraživanja i javno mnjenje.

Bakshy, Eytan, Solomon Messing, and Lada Adamic. 2015. "Exposure to Ideologically Diverse News and Opinion on Facebook." Science 348 (6239): 1130-1133.

Berardi, Lorenzo. 2019. "Distortion and Propaganda in Hungarian Media - an Interview with Sándor Orbán.” Reset Dialogues on Civilisations. March 28. Accessed: September 20, 2019. https://www.resetdoc.org/story/distortion-propagandahungarian-media-interview-sandor-orban/.

Block, Elena, and Ralph Negrine. 2017. “The Populist Communication Style: Toward a Critical Framework." International Journal of Communication 11 (20): 178-197.

Boorstin, Daniel J.1992. The Image: A Guide to Pseudo-Events in America. New York: Vintage Books.

Bugarič, Bojan. 2019. “Central Europe's Descent into Autocracy: A Constitutional Analysis of Authoritarian Populism." International Journal of Constitutional Law 17 (2): 597-616.

Byers, Dylan, and Jeremy Diamond. 2016. "Donald Trump's 'sleaze' attack on reporter hits new level of media animosity”. CNN. May 31. Accessed: September 22, 2016. https://money.cnn.com/2016/05/31/media/donald-trump-reporter-sleaze/.

Caplan, Lincoln. 2018. "Stress Test for Free Speech: Social Media are Destroying the Democratic Culture That the First Amendment Is Meant to Protect." American Scholar 87 (4): 20 .

Carlson, Matt. 2017. Journalistic Authority: Legitimating News in the Digital Era. New York: Columbia University Press.

Carlson, Matt. 2018. "The Information Politics of Journalism in a Post-Truth Age." Journalism Studies 19 (13): 1879-1888.

Csigo, Peter, and Norbert Markovity. 2017. "Hungary”. In: Populist Political Communication in Europe, edited by Toril Aalberg, Frank Esser, Carsten Reinemann, Jesper Stromback, and Claes De Vreese, 299-311. New York: Routledge.

Dawson, James, and Sean Hanley. 2016. "What's Wrong with East-Central Europe? The Fading Mirage 'Liberal Consensus"'. Journal of Democracy 27 (1): 20-34. 
Doner, Fatma Nil. 2019. “Trump's Wisdom for the International Political Economy: A Way to Collective Carnage?" Perceptions: Journal of International Affairs 24 (1): 105-30.

Elçi, Ezgi. 2019. “The Rise of Populism in Turkey: A Content Analysis.” Journal of Southeast European E Black Sea Studies 19 (3): 387-408.

European Commission. 2019. Serbia Report 2019. Accessed: September 13, 2019. https://ec.europa.eu/neighbourhood-enlargement/sites/near/files/20190529-serbiareport.pdf.

Freedom House. 2019. Media Freedom Report/Serbia 2019. Accessed: September 13, 2019. https://freedomhouse.org/report/freedom-media/freedom-media-2019.

Freie, John. 2012. “Postmodern Politics in America." Society 49 (9): 323.

Goodman, Adam. 2017. “The Long History of Self-Deportation.” NACLA Report on the Americas 49 (2): 152.

Habermas, Jürgen. 1974. “The Public Sphere: An Encyclopedia Article.” New German Critique 3: 49-55.

Havlik, Vlastimil. 2019. “Technocratic Populism and Political Illiberalism in Central Europe." Problems of Post-Communism 66 (6): 369.

Inglehart, Ronald F., and Pippa Norris. 2016. "Trump, Brexit, and the Rise of Populism: Economic Have-Nots and Cultural Backlash." HKS Faculty Research Working Paper No. RWP16-026. Harvard: Kennedy School, Harvard Univeristy.

Jagers, Jan, and Stefan Walgrave. 2007. "Populism as Political Communication Style: An Empirical Study of Political Parties' discourse in Belgium." European Journal of Political Research 46 (3): 319-345.

Jevtić, Milica. 2016. "Hibridizacija faktografskih žanrova: Činjenice su svete, jesu li komentari slobodni?” Godišnjak Fakulteta političkih nauka 16 (2): 55-70.

Kayam, Orly. 2018. “The Readability and Simplicity of Donald Trump's Language." Political Studies Review 16 (1): 73-88.

Kellner, Douglas. 2016. American Nightmare: Donald Trump, Media Spectacle, and Authoritarian Populism. Rotterdam: Sense Publishers.

Kreuder-Sonnen, Christian. 2018. "An authoritarian turn in Europe and European Studies?” Journal of European Public Policy 25 (3): 452-464. 
Lockie, Stewart. 2017. "Post-truth Politics and the Social Sciences." Environmental Sociology 3 (1): 1-5.

Massing, Michale. 2018. "Journalism in the Age of Trump." The Nation. August 2. Accessed: September 14, 2019. https://www.thenation.com/article/archive/journalismage-trump-whats-missing-matters/.

Mazzoleni, Gianpietro. 2008. "Populism and the media". In Twenty-First Century Populism, edited by Daniele Albertazzi and Duncan McDonnell, 49-64. London: Palgrave Macmillan.

McCarthy Tom. 2019. “'No, You're Corrupt!: Why There's Method in Trump's Playground Taunts." The Guardian. September 24. Accessed: September 25, 2019. https:// www.theguardian.com/us-news/2019/sep/24/donald-trump-joe-biden-ukraine.

McCoy, Jennifer, Tahmina Rahman, and Murat Somer. 2018. "Polarization and the Global Crisis of Democracy: Common Patterns, Dynamics, and Pernicious Consequences for Democratic Polities." American Behavioral Scientist 62 (1): 16-42.

McDevitt, Michael, and Patrick Ferrucci. 2018. "Populism, Journalism, and the Limits of Reflexivity." Journalism Studies 19 (4): 512-526.

McIntyre, Lee. 2019. Post-Truth. Cambridge: The MIT Press.

Milosavljević, Marko, and Melita Polar. 2019. "Balkanization and Pauperization: Analysis of Media Capture of Public Service Broadcasters in the Western Balkans." Journalism 19 (8): 1149-1164.

Mladenov Jovanović, Srđan. 2018."'You're Simply the Best': Communicating Power and Victimhood in Support of President Aleksandar Vučić in the Serbian Dailies Alo! and Informer." Journal of Media Research 31 (11): 22-42.

Mladenov Jovanović, Srđan. 2019. "Confronting Recent History Media in Serbia During Aleksandar Vučić's Ministry of Information in the Milošević Era (1998-1999)." Hiperboreea 6 (1): 61-74.

Mudde, Cas, and Cristobal Rovira Kaltwasser. 2013. "Exclusionary vs. Inclusionary Populism: Comparing Contemporary Europe and Latin America." Government and Opposition 48 (2): 147-174.

Mudde, Cas. 2004. “The Populist Zeitgeist." Government and Opposition 39 (4): 541-563. 
N1. 2018. "Vučić ne odustaje od etiketiranja medija”. October 18. Accessed: September 15, 2019. http://rs.n1 info.com/Vesti/a428864/Vucic-ne-odustaje-od-etiketiranjamedija.html.

N1. 2019. "Plenković u raspravi sa N1 o napadu kod Knina: Vi ste aktivista, a ne novinar." August 23. Accessed: September 15, 2019. http://rs.n1info.com/Region/ a510027/Plenkovic-u-raspravi-sa-reporetrom-N1-o-napadu-kod-Knina.html.

Otjes, Simon, Gilles Ivaldi, Andres Ravlik Jupskas, and Oscar Mazzoleni. 2018. “It's not Economic Interventionism, Stupid! Reassessing the Political Economy of Radical Right-wing Populist Parties." Swiss Political Science Review 24: 270-290.

Oxford Dictionary. No date. “The Post-Truth”. Accessed: September 12, 2019. https:// www.oxfordlearnersdictionaries.com/definition/english/post-truth.

Pavkov, Ksenija. 2019. "Vučićeva savetnica brzinom munje sipala neistine o N1 na nacionalnoj frekvenciji." Cenzolovka. November 18. Accessed: April 10, 2020. https:// www.cenzolovka.rs/pritisci-i-napadi/vuciceva-savetnica-brzinom-munje-sipalaneistine-o-n1-na-nacionalnoj-frekvenciji/.

Pepper, Tara. 2005. “Making Their Own Breaks." Newsweek (Atlantic Edition) 146 $(13 / 14): 82$.

Pope, Kyle. 2019. “Beyond Facts." Columbia Journalism Review. Accessed: January 30, 2020 https://www.cjr.org/special_report/beyond-facts-disinformation.php.

Reporters Without Borders. 2019. United States of America 2019. Accessed: April 1, 2020. https://rsf.org/en/2019-world-press-freedom-index-cycle-fear.

Reporters Without Borders. 2019a. Serbia 2019. Accessed: September 13, 2019. https://rsf.org/en/Serbia.

Reuters Institute for Study of Journalism. No date. Digital News Report 2019. Accessed: September 8, 2019. http://www.digitalnewsreport.org/.

Rovere, Richard H. 1996. Senator Joe McCarthy. Oakland: University of California Press.

Rowland, Robert C. “The Populist and Nationalist Roots of Trump's Rhetoric." Rhetoric $\mathcal{E}$ Public Affairs 22 (3): 343-88.

Savage, Charlie. 2019. “Trump Can't Block Critics from His Twitter Account, Appeals Court Rules”. New York Times. July 9. Accessed: September 12, 2019. https:// www.nytimes.com/2019/07/09/us/politics/trump-twitter-first-amendment.html. 
Scott, Anthony, Stephen Coleman, and David E. Morrison David. 2019. Public Trust in the News: A Constructivist Study of the Social Life of the News. Oxford: Reuters Institute for the Study of Journalism.

Selva, Meera. 2020. "Journalism under Fire". In Journalism, Media, and Technology Trends and Predictions 2020, edited by Nic Newman, 28-30. University of Oxford: Reuters Institute for the Study of Journalism.

Shaheen, Kareem. 2016. “Turkish Journalist Accuse Erdogan of Media Which Hunt.” The Guardian. May 2. Accessed: September 12, 2019. https:/www.theguardian.com/ world/2016/may/02/turkish-journalists-accuse-erdogan-of-media-witch-hunt.

Society of Professional Journalists. 2014. Code of Ethics. Accessed: September 12, 2019. https://www.spj.org/pdf/spj-code-of-ethics-bookmark.pdf.

Somer, Murat, and Jennifer McCoy. 2019. "Transformations through Polarizations and Global Threats to Democracy. The Annals of the American Academy of Political and Social Science 681 (1): 8-22.

Stelter, Brian, Marshall Cohen, David Shortell, and Jessica Schneider. 2018. "Judge Orders White House to Return Jim Acosta's Press Pass." CNN. November 16. Accessed: September 12, 2019. https://edition.cnn.com/2018/11/16/media/cnn-trumplawsuit-hearing/index.html.

Strandberg, Thomas, Jay A Olson, Lars Hall, Andy Woods, and Petter Johansson. 2020. "Depolarizing American Voters. Democrats and Republicans Are Equally Susceptible to False Attitude Feedback.” PLoS ONE 15 (2): e0226799.

Turk, Bahadir H. 2018. "Populism as a Medium of Mass-mobilisation: The Case of Recep Tayyip Erdoğan.” International Area Studies Review 21 (2): 150-168.

TV Happy. 2018. “Ćirilica”. November 19. Accessed September 23 2019. https://www. youtube.com/watch?v=OMMNVWgm0Ps.

Vučić, Aleksandar. "Elita i plebs.” Politika. July 10. Accessed: September 20, 2019. http://www.politika.rs/scc/clanak/433411/Elita-i-plebs.

White House. 2017. Remarks by President Trump in Press Conference. February 16. Accessed: September 27, 2019. https://www.whitehouse.gov/briefings-statements/ remarks-president-trump-press-conference/.

White House. 2018. Remarks by President Trump in Press Conference After Midterm Elections. November 7. Accessed: September 1, 2019. https://www.whitehouse.gov/ 
briefings-statements/remarks-president-trump-press-conference-midterm-elections/.

White House. 2018a. Remarks by President Trump on the United States-MexicoCanada Agreement. October 1. Accessed: September 27, 2019. https://www.whitehouse.gov/briefings-statements/remarks-president-trump-united-states-mexicocanada-agreement/.

White House. 2019. Remarks by President Trump Before Marine One Departure. August 21. Accessed November 27, 2019. https://www.whitehouse.gov/briefingsstatements/remarks-president-trump-marine-one-departure-60/.

White House. 2019a. Remarks by President Trump in Press Conference. September 25. Accessed: September 28, 2019. https://www.whitehouse.gov/briefingsstatements/remarks-president-trump-press-conference-3/.

White House. 2019b. Remarks by President Trump and President Niinistö of the Republic of Finland in Joint Press Conference. October 2. Accessed October 3, 2019. https://www.whitehouse.gov/briefings-statements/remarks-president-trumppresident-niinisto-republic-finland-joint-press-conference/.

Zelizer, Barbie. 2018. "Resetting Journalism in the Aftermath of Brexit and Trump". European Journal of Communication 33 (2): 140-156. 